\title{
PENGEMBANGAN PANDUAN LAYANAN KESEHATAN MENTAL BERBASIS SEKOLAH BAGI ANAK BERKEBUTUHAN KHUSUS
}

\author{
Atien Nur Chamidah, Purwandari, dan Aini Mahabbati \\ Universitas Negeri Yogyakarta \\ Email: atien@uny.ac.id
}

\begin{abstract}
Abstrak
Penelitian ini bertujuan untuk memvalidasi model dan menghasilkan buku panduan layanan kesehatan mental berbasis sekolah bagi anak berkebutuhan khusus. Penelitian menggunakan pendekatan Research and Development. Subjek dalam penelitian ini adalah praktisi kesehatan mental di sekolah, dan praktisi lain yang terlibat dalam layanan kesehatan mental (psikolog dan dokter), dan pengguna (guru) di SLB di Daerah Istimewa Yogyakarta. Data penelitian akan dikumpulkan melalui kuosioner dan Focus Group Discussion (FGD) serta akan dilakukan analisis secara deskriptif kualitatif serta kuantitatif. Rangkaian kegiatan penelitian ini menghasilkan produk akhir berupa buku panduan layanan kesehatan mental berbasis sekolah bagi anak berkebutuhan khusus yang telah diuji validasi oleh subjek penelitian. Penelitian selanjutnya diharapkan akan menjadi penelitian ujicoba produk dalam skala yang lebih besar.
\end{abstract}

Kata kunci: layanan kesehatan mental berbasis sekolah, anak berkebutuhan khusus

\section{DEVELOPING SCHOOL-BASED MENTAL HEALTH SERVICE GUIDEBOOK FOR CHILDREN WITH SPECIAL NEEDS}

\begin{abstract}
This research aims to validate model and develop school-based mental health service guidebook for children with special needs. Employing Research and Development approach, this research is involving subjects such as mental health practitioners, psychologists and physician, and teachers from several special schools in the Yogyakarta Special Province. The data were collected with questionnaire and Forum Group Discussion (FGD). Subsequently, the obtained data descriptively analyzed with quantitative and qualitative approaches. As the final result of this research will be a validated guidebook of school-based mental health services for children with special needs. Furthermore, the next research is projected to focus on tryouts with a larger amount of research subjects.
\end{abstract}

Keywords: school-based mental health, children with special needs

\section{PENDAHULUAN}

Anak berkebutuhan khusus (ABK) mempunyai risiko tinggi mengalami berbagai masalah gangguan kesehatan mental. Wujud dari gangguan kesehatan mental tersebut berupa gangguan mental di luar karakteristik dan kebutuhan khusus anak. Gangguan dapat berupa depresi, kecemasan, gangguan stres, gangguan kepriba- dian, psikosis, dan skizofrenia (Hudson dan Chan, 2002:47). Penelitian Balogh et al (2010:830) di Kanada juga menemukan bahwa ABK terutama yang mempunyai disabilitas intelektual berisiko 15 kali lebih tinggi untuk dirawat karena diagnosis skizofrenia dibanding populasi anak pada umumnya. Adapun di Indonesia, penelitian sebelumnya oleh Purwandari, 
Aini Mahabbati, dan Atien Nur Chamidah (2013:10) menemukan bahwa jenis gangguan kesehatan mental pada ABK yang bersekolah di SLB di DIY berupa gangguan perilaku dalam pembelajaran, perilaku bermasalah komunikasi dan sosial; perilaku bermasalah internal seperti stress, depresi, melukai diri sendiri; perilaku bermasalah eksternal seperti perilaku agresif, mengganggu, dan membangkang guru; serta gangguan perilaku seksual.

Tingginya kasus dan variasi masalah kesehatan mental pada ABK tidak diimbangi dengan akses layanan kesehatan mental yang mereka dapatkan. Penelitian sebelumnya menunjukkan bahwa orangtua ABK di SLB di DIY pada umumnya sangat tergantung pada sekolah dalam penanganan kasus gangguan kesehatan mental anak (Purwandari, Aini Mahabbati, dan Atien Nur Chamidah, 2013:11). Hal ini searah dengan penelitian Chan, Hudson dan Vulic (2004:5), yang menyatakan jumlah ABK yang mengakses layanan kesehatan mental lebih rendah jika dibandingkan populasi pada umumnya. Hudson dan Chan (2002:47) menyebutkan tiga hambatan utamanya, yaitu kurangnya pengetahuan para praktisi kesehatan mental mengenai $A B K$, kurangnya ahli yang khusus mendalami, dan hambatan komunikasi antara klinisi dan individu berkebutuhan khusus.

Padahal, intervensi yang berhasil dapat menurunkan insidensi kasus baru dan menurunkan prevalensi gangguan kesehatan mental secara keseluruhan. Kajian Paternite (2005:659) menunjukkan bahwa program kesehatan mental berbasis sekolah tidak hanya meningkatkan akses layanan kesehatan mental bagi anak, tetapi juga menurunkan stigma negatif terhadap gangguan mental. Selain itu, dengan adanya layanan kesehatan mental yang diberikan sejak dini, maka pencegahan gangguan mental berat pada usia dewasa dapat dicegah (Caruana et al, 2011:342). Lebih lanjut, intervensi dini dapat menurunkan terjadinya masalah sosial dan ekonomi yang mungkin terjadi apabila anak berkebutuhan khusus mengalami gangguan mental (Caruana et al, 2011:344).

Salah satu langkah strategis untuk mengupayakan layanan kesehatan mental bagi ABK adalah mengoptimalkan peran sekolah. Sebagaimana Paternite (2005:658) menyatakan bahwa Program kesehatan mental terpadu berbasis masyarakat dengan sekolah sebagai salah satu kunci utama pelaksana program merupakan salah satu solusi untuk meningkatkan layanan kesehatan bagi anak. Sekolah menyumbang dampak positif bagi perkembangan anak sehingga sekolah mempunyai peran penting dan, menurut WHO menjadi tempat terbaik dalam melakukan promosi dan intervensi mengenai kesehatan mental menunjukkan bahwa (Caruana et al, 2011:344).

Penelitian Purwandari, Aini Mahabbati, dan Atien Nur Chamidah (2013) sebelumnya menemukan bahwa banyak SLB di DIY yang telah memiliki fasilitas penunjang layanan kesehatan mental beserta tim petugasnya. Layanan tersebut salah satunya berbentuk Unit Kesehatan Sekolah (UKS), yang bahkan telah didukung pelaksanaannya dengan Surat Keputusan (SK) Kepala Dinas Pendidikan, Pemuda, dan Olahraga DIY Nomor 065 Tahun 2013. Layanan pendukungnya berupa kerjasama dengan ahli terkait seperti tenaga kesehatan, psikolog, dan terapis kebutuhan khusus. Namun demikian, hasil penelitian menunjukkan bahwa layanan kesehatan mental tersebut masih belum memiliki formulasi yang tersistem. Seringkali layanan diadakan hanya secara insidental saja apabila ditemukan kasus gangguan kesehatan mental pada anak. Pada umumnya guru kelas menjadi penanggung jawab utama karena menjadi pihak yang pertama kali menjumpai kasus di ruang kelas. Para petugas layanan kesehatan mental SLB juga menyatakan pentingnya 
perumusan alur layanan kesehatan mental secara berkala maupun insidental, kerjasama dengan profesional, dan pengembangan layanan untuk kasus-kasus berat, yang kesemuanya diformat dalam program yang terencana dan berkelanjutan. Masalah layanan kesehatan mental di SLB DIY tersebut sesuai dengan penelitian Caruana et al (2011:344) yang menunjukkan belum adanya suatu formulasi yang tepat dan terbatasnya layanan kesehatan mental bagi anak berkebutuhan khusus di sekolah.

Berdasarkan temuan penelitian terdahulu dan beberapa kajian atas temuan penelitian lain, maka diperlukan penelitian yang menghasilkan suatu panduan layanan kesehatan mental yang memiliki alur yang tersistem. Panduan disusun berdasarkan kebutuhan akan perbaikan layanan kesehatan mental di SLB yang ditemukan dari penelitian sebelumnya, yakni dimulai dari asesmen kebutuhan khusus dan asesmen problem kesehatan mental sebagai dasar layanan, identifikasi gejala kesehatan mental pada ABK, berbagai intervensi yang bisa diberikan sesuai dengan kasus, kolaborasi dengan ahli lain, dukungan dan pendidikan untuk orangtua, dan pengembangan komunitas sekolah yang promotif terhadap kesehatan mental anak.

Penelitian ini diharapkan menghasilkan luaran berupa buku panduan layanan kesehatan mental berbasis sekolah untuk anak berkebutuhan khusus. Penelitian ini didasari temuan dari penelitian Purwandari, Aini Mahabbati, dan Atien Nur Chamidah (2013) sebelumnya mengenai pengembangan model layanan kesehatan mental berbasis sekolah untuk anak berkebutuhan khusus di DIY. Penelitian ini menemukan tingginya prevalensi dan variasi kasus gangguan kesehatan mental pada ABK di SLB di DIY, layanan yang sudah tersedia, dan kebutuhan akan panduan alur layanan kesehatan mental yang terprogram.
Secara internasional penelitian mengenai layanan kesehatan mental bagi ABK dilakukan oleh Chan, Hudson dan Vulic (2004:5) yang menyatakan jumlah ABK yang mengakses layanan kesehatan mental lebih rendah jika dibandingkan populasi pada umumnya. Caruana et al (2011:345) meneliti tentang kesehatan mental pada ABK dan menyatakan bahwa layanan kesehatan mental pada ABK yang dilaksanakan secara dini dapat berdampak positif bagi perkembangan kesehatan mental ABK. Penelitian Caruana et al (2011:345) juga menunjukkan bahwa sekolah berperan penting sebagai lembaga yang strategis dan menjadi pusat layanan kesehatan mental ABK.

\section{METODE}

Penelitian menggunakan pendekatan Research and Development yang mengacu pada rancangan model dari Borg dan Gall (1983:64), yaitu model pengembangan yang menghasilkan produk tertentu. Produk yang akan dihasilkan pada penelitian ini adalah buku panduan layanan kesehatan mental berbasis sekolah untuk anak berkebutuhan khusus.

Dasar penelitian ini adalah penelitian pendahuluan yang dilaksanakan Purwandari, Aini Mahabbati, dan Atien Nur Chamidah (2013) yang menganalisis kasus dan variasi gangguan kesehatan mental pada $A B K$, sumber daya layanan kesehatan mental di sekolah, dan kebutuhan akan pengembangan layanan kesehatan mental berbasis sekolah yang memiliki alur yang jelas. Produk awal penelitian pendahuluan tersebut adalah rancangan buku panduan layanan kesehatan mental. Rancangan buku panduan tersebut berdasar pada dimensi layanan yang akan dikembangkan dalam program.

Berdasarkan hasil yang dicapai pada tahun pertama, selanjutnya pada tahun kedua akan dilakukan ujicoba validasi model serta evaluasi hasil uji coba model tersebut. Validasi model dilakukan dengan 
mengajak pakar materi layanan kesehatan mental, praktisi pemberi layanan kesehatan mental, guru, kepala sekolah, dan instansi terkait dengan mengikuti langkah sebagai berikut:

1. Melakukan uji lapangan permulaan rancangan model (dilakukan pada subjek yang terdiri dari ahli layanan kesehatan mental, praktisi pemberi layanan kesehatan mental, guru, kepala sekolah, dan instansi terkait).

2. Melakukan uji lapangan permulaan rancangan buku pedoman layanan (dilakukan pada subjek yang terdiri dari ahli layanan kesehatan mental, ahli media, dan guru).

3. Melakukan revisi dari hasil uji lapangan permulaan.

4. Melakukan uji lapangan utama model dan buku pedoman layanan (pada subjek guru SLB).

5. Melakukan revisi dari uji lapangan utama.

Rancangan penelitian lanjutan ini berupa penelitian uji validasi model serta evaluasi hasil uji coba model tersebut. Produk yang dihasilkan adalah panduan layanan kesehatan mental berbasis sekolah untuk ABK berdasarkan temuan pada pe- nelitian pendahuluan. Validasi melibatkan ahli materi kesehatan mental (petugas kesehatan mental di sekolah, ahli terkait) dan kelompok kecil pengguna (guru). Alur validasi tergambar dalam Gambar1.

Subjek dalam penelitian ini adalah guru, kepala sekolah, dan praktisi lain yang terlibat dalam layanan kesehatan mental (psikolog, psikiater, dokter umum, dan terapis) di SLB Daerah Istimewa Yogyakarta. Subjek akan diperoleh secara proporsional purposive random sampling. Variabel penelitian yang menjadi pusat perhatian dalam penelitian pertama ini adalah jenis kebutuhan layanan kesehatan mental bagi anak berkebutuhan khusus dan potensi pendukung layanan kesehatan mental di sekolah.

Data penelitian dikumpulkan melalui kuesioner kelayakan buku panduan yang diisi subjek. Oleh karena itu dibutuhkan instrumen penelitian berupa kuesioner kelayakan buku panduan. Sesuai dengan tujuan penelitian, analisis data dilakukan secara deskriptif kualitatif dan kuantitatif berdasarkan temuan pada kuosioner kelayakan. Berdasarkan data tersebut selanjutnya disusun produk akhir buku panduan layanan kesehatan mental ber-

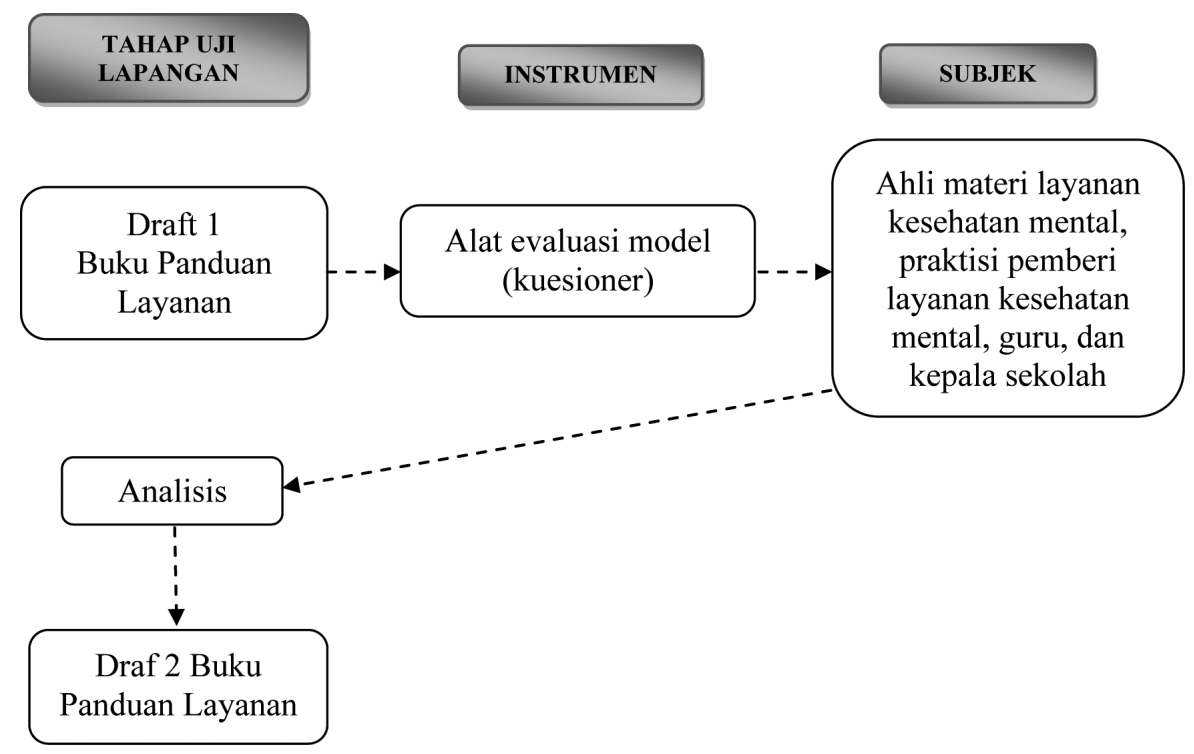

Gambar 1. Rancangan Validasi Model Layanan Kesehatan Mental Berbasis Sekolah 
basis sekolah untuk ABK yang siap untuk diujicobakan secara lebih luas pada penelitian selanjutnya.

\section{HASIL DAN PEMBAHASAN}

A. Penyusunan Draft Panduan Layanan Kesehatan Mental Berbasis Sekolah bagi Anak Berkebutuhan Khusus

Pada tahap ini, peneliti melakukan studi literatur untuk pengembangan buku panduan layanan kesehatan mental berbasis sekolah bagi anak berkebutuhan khusus. Kegiatan ini dilakukan dengan cara literatur eksploratorik melalui pengkajian berbagai teori yang berkaitan dengan kesehatan mental. Hasil studi literatur dijadikan acuan untuk menyusun kisi-kisi buku panduan yang meliputi:.

1. Pendahuluan; berisi tentang latar belakang, tujuan dan manfaat buku serta sistematika dan ruang lingkup buku.

a. Latar Belakang; Pada bagian ini dijelaskan mengenai latar belakang perlunya penyelenggaraan layanan kesehatan mental bagi anak berkebutuhan khusus di sekolah

b. Tujuan dan Manfaat Buku Panduan; Dalam tujuan dan manfaat juga dijelaskan untuk apa dibuat tujuan serta manfaat buku panduan disusun.

c. Sistematika dan ruang lingkup buku; Bagian ini menjelaskan tentang sistematika dan ruang lingkup buku panduan yang terdiri dari masalah kesehatan mental pada anak berkebutuhan khusus, model layanan kesehatan mental berbasis sekolah pada anak berkebutuhan khusus, dan kolaborasi antar profesional dalam memberikan layanan kesehatan mental berbasis sekolah bagi anak berkebutuhan khusus.

2. Masalah Kesehatan Mental pada Anak Berkebutuhan Khusus; yang dibahas dalam buku ini terbatas pada masalah kesehatan mental yang banyak terjadi pada anak berkebutuhan, terutama berbagai masalah yang telah teridentifikasi pada tahap penelitian sebelumnya. Masalah tersebut meliputi depresi, anxietas/kecemasan, gangguan stres paska trauma, gangguan perilaku, psikosis, dan gangguan seksual. Pada masing-masing masalah tersebut dijelaskan pengertian serta gejala-gejala yang muncul sebagai landasan untuk mengenali terjadinya gangguan kesehatan mental pada anak berkebutuhan khusus.

3. Model Layanan Kesehatan Mental Berbasis Sekolah bagi Anak Berkebutuhan Khusus; Bagian ini menjelaskan tentang model layanan yang telah dikembangkan pada penelitian sebelumnya. Selain itu, pada bagian ini dijelaskan pula tentang faktor protektif dan risiko terhadap kesehatan mental anak berkebutuhan khusus serta faktor penunjang keberhasilan program. Model layanan kesehatan mental yang dikembangkan terdiri dari empat dimensi layanan (Purwandari, Atien Nur Chamidah, Aini Mahabbati, 2013) yaitu:

a. Pengembangan komunitas sekolah yang positif.

b. Pembelajaran sosial emosi.

c. Dukungan dan pendidikan untuk orang tua.

d. Intervensi dini masalah kesehatan mental.

4. Kolaborasi Antar Profesional dalam Layanan Kesehatan Mental Berbasis Sekolah bagi Anak Berkebutuhan Khusus; Kolaborasi antarahli merupakan bagian penting dari terselenggaranya layanan kesehatan mental di sekolah. Pada buku ini dijelaskan tentang peran masing-masing ahli serta kerjasama yang perlu dikembangkan oleh sekolah dengan pihak lain yang dapat mendukung pelaksanaan layanan.

Secara skema rancangan buku panduan dapat dilihat pada Tabel 2. 
Tabel 2. Rancangan Buku Panduan

\begin{tabular}{lll}
\hline No & \multicolumn{1}{c}{ Komponen } & \multicolumn{1}{c}{ Materi } \\
\hline 1 & Cover & Judul buku, penulis, tahun \\
\hline 2 & Kata Pengantar & \\
\hline 3 & Daftar Isi & \\
\hline 4 & BAB I. Pendahuluan & a. Latar Belakang \\
& & b. Tujuan dan Manfaat \\
& & c. Sistematika dan ruang lingkup buku \\
\hline 5 & BAB II. Masalah Kesehatan & a. Depresi \\
& Mental pada Anak & b. Anxietas/kecemasan \\
& Berkebutuhan Khusus & c. Gangguan stres paska trauma \\
& & d. Gangguan perilaku \\
& & e. Psikosis \\
\hline 6 & BAB III. Model Layanan & f. Gangguan seksual \\
& Kesehatan Mental Berbasis & aktor protektif dan risiko terhadap kesehatan mental \\
& Sekolah bagi Anak & b. Faktor penunjang keberhasilan program \\
& Berkebutuhan Khusus & c. Dimensi Layanan Kesehatan Mental di \\
& & Sekolah
\end{tabular}

\section{B. Validasi Ahli}

Validasi ahli dilakukan dengan cara memberikan angket yang mencakup penilaian terhadap seluruh isi/materi rancangan buku panduan layanan kesehatan mental berbasis sekolah bagi anak berkebutuhan khusus serta penilaian terhadap kebermanfaatan, kelayakan, dan kesesuaian buku. Ahli yang dilibatkan adalah ahli psikologi anak berkebutuhan khusus yaitu Dra. Tin Suharmini, M.Si dan ahli pendidikan khusus yaitu Dra. Endang Supartini, M.Pd. Hasil penilaian angket validasi ahli yang diperoleh digunakan untuk mengetahui perlu tidaknya peneliti merevisi rancangan buku panduan.

Hasil validasi ahli terhadap isi atau materi rancangan buku panduan dapat dilihat pada Tabel 3.

Berdasarkan Tabel 3, hasil data yang diperoleh dari penilaian ahli materi menunjukkan bahwa 15 indikator draf panduan yang dinilai oleh validator ahli Idisimpulkan 11 indikator (73\%) dinyatakan sangat relevan, 4 indikator $(27 \%)$ dinyatakan relevan. Sedangkan, validator ahli II memberikan penilaian 100\% relevan.
Berdasarkan penilaian kedua validator tersebut dapat disimpulkan bahwa buku panduan yang telah dibuat peneliti dari sisi materi dinyatakan layak diuji coba pada tahap selanjutnya dengan melakukan revisi atas saran dan masukan validator.

Adapun hasil penilaian terhadap kebermanfaatan, kelayakan, dan kesesuaian buku secara rinci tersaji pada Tabel 4 .

Berdasarkan data yang tersaji pada Tabel 4 dapat dilihat bahwa jumlah skor yang diberikan oleh Ahli I adalah 58 (97\%) dari total skor maksimal yang dapat diperoleh adalah 60, sedangkan Ahli II memberikan skor 56 (93\%). Berdasarkan penilaian tersebut, maka buku panduan yang telah dibuat peneliti dinyatakan bermanfaat dan sesuai bagi pengguna serta layak diuji coba lapangan dengan revisi sesuai saran yang telah diberikan.

\section{Revisi Hasil Validasi}

Revisi dilakukan berdasarkan saran dari ahli yang mencakup hal-hal berikut.

a. Pendahuluan diperbaiki dengan menambahkan tentang kriteria mental yang sehat, sasaran pengguna buku 
Tabel 3. Hasil Validasi Isi/Materi

\begin{tabular}{|c|c|c|c|}
\hline \multirow[t]{2}{*}{ Komponen } & \multirow[t]{2}{*}{ Indikator } & \multicolumn{2}{|c|}{ Penilaian } \\
\hline & & Ahli I & Ahli II \\
\hline \multirow[t]{3}{*}{ Pendahuluan } & Latar Belakang & Sangat relevan & Relevan \\
\hline & $\begin{array}{l}\text { Tujuan dan Manfaat } \\
\text { Buku }\end{array}$ & Sangat relevan & Relevan \\
\hline & $\begin{array}{l}\text { Sistematika dan Ruang } \\
\text { Lingkup Buku }\end{array}$ & Sangat relevan & Relevan \\
\hline \multirow{6}{*}{$\begin{array}{l}\text { Model Layanan Kesehatan } \\
\text { Mental Berbasis Sekolah } \\
\text { bagi ABK }\end{array}$} & Depresi & Sangat relevan & Relevan \\
\hline & Anxietas/Kecemasan & Relevan & Relevan \\
\hline & $\begin{array}{l}\text { Gangguan Stres Paska } \\
\text { Trauma }\end{array}$ & Sangat relevan & Relevan \\
\hline & Gangguan Perilaku & Relevan & Relevan \\
\hline & Gangguan Seksual & Sangat relevan & Relevan \\
\hline & Psikosis & Sangat relevan & Relevan \\
\hline \multirow[t]{3}{*}{$\begin{array}{l}\text { Model Layanan Kesehatan } \\
\text { Mental Berbasis Sekolah } \\
\text { bagi ABK }\end{array}$} & $\begin{array}{l}\text { Faktor Protektif dan } \\
\text { Risiko terhadap } \\
\text { Kesehatan Mental ABK }\end{array}$ & Relevan & Relevan \\
\hline & $\begin{array}{l}\text { Faktor Penunjang } \\
\text { Keberhasilan Program } \\
\text { Layanan Kesehatan } \\
\text { Mental ABK }\end{array}$ & Sangat relevan & Relevan \\
\hline & $\begin{array}{l}\text { Dimensi Layanan } \\
\text { Kesehatan Mental }\end{array}$ & Sangat relevan & Relevan \\
\hline \multicolumn{2}{|c|}{$\begin{array}{l}\text { Kolaborasi antarprofesional dalam LayananKesehatan } \\
\text { MentalBerbasis Sekolah }\end{array}$} & Relevan & Relevan \\
\hline \multicolumn{2}{|l|}{ Penutup } & Sangat relevan & Relevan \\
\hline
\end{tabular}

yang terdeskripsi dengan jelas, serta mendeskripsikan prosedur penggunaan buku dengan rinci.

b. Masalah kesehatan mental diperbaiki dengan menambahkan contoh-contoh kecemasan yang sering muncul pada ABK seperti fobia. Pada bagian gangguan perilaku juga ditambahkan contoh yang nyata dan jelas.

c. Model layanan kesehatan mental diperbaiki dengan menambahkan pemberian feedback yang realistis sebagai salah satu faktor protektif terhadap masalah kesehatan mental.

d. Memperbaiki kolaborasi antarprofesional diperbaiki dengan memper- jelas peran masing-masing ahli serta menambahkan peran psikolog dalam memberikan layanan kesehatan mental bagi ABK di sekolah.

\section{PENUTUP}

Penyusunan buku panduan layanan kesehatan mental berbasis sekolah bagi anak berkebutuhan khusus disusun dengan materi berupa: masalah kesehatan mental pada anak berkebutuhan khusus, model layanan kesehatan mental berbasis sekolah pada anak berkebutuhan khusus, dan kolaborasi antar profesional dalam memberikan layanan kesehatan mental berbasis sekolah bagi anak berkebutuh- 
Tabel 4. Hasil Validasi Ahli terhadap Kebermanfaatan, Kelayakan, dan Kesesuaian Rancangan Buku Panduan

\begin{tabular}{|c|c|c|c|}
\hline \multirow[t]{2}{*}{ Aspek } & \multirow[t]{2}{*}{ Hal } & \multicolumn{2}{|c|}{ Skor } \\
\hline & & Ahli I & Ahli II \\
\hline \multirow[t]{8}{*}{ Kebermanfaatan } & $\begin{array}{l}\text { Sasaran pengguna buku teridentifikasi dengan } \\
\text { jelas }\end{array}$ & 3 & 5 \\
\hline & $\begin{array}{l}\text { Pengguna buku mempunyai kompetensi yang } \\
\text { sesuai }\end{array}$ & 5 & 5 \\
\hline & $\begin{array}{l}\text { Materi buku panduan sesuai dengan kebutuhan } \\
\text { dari pengguna }\end{array}$ & 6 & 5 \\
\hline & $\begin{array}{l}\text { Prosedur penggunaan buku terdeskripsi dengan } \\
\text { jelas }\end{array}$ & 3 & 4 \\
\hline & $\begin{array}{l}\text { Pembaca mendapat kejelasan mengenai isi } \\
\text { buku: }\end{array}$ & & \\
\hline & $\begin{array}{l}\text { 1) Jenis-jenis gangguan kesehatan mental pada } \\
\text { ABK }\end{array}$ & 5 & 5 \\
\hline & $\begin{array}{l}\text { 2) Model layanan kesehatan mental berbasis } \\
\text { sekolah bagi ABK }\end{array}$ & 5 & 5 \\
\hline & $\begin{array}{l}\text { 3) Kolaborasi ahli dalam penanganan kesehatan } \\
\text { mental }\end{array}$ & 5 & 5 \\
\hline \multirow[t]{3}{*}{ Kelayakan } & $\begin{array}{l}\text { Buku panduan praktis diterapkan karena } \\
\text { informasi yang diperlukan terdeskripsi dengan } \\
\text { jelas }\end{array}$ & 5 & 4 \\
\hline & $\begin{array}{l}\text { Buku panduan dapat diterapkan oleh berbagai } \\
\text { latar belakang pendidikan guru }\end{array}$ & 5 & 4 \\
\hline & $\begin{array}{l}\text { Buku panduan memberikan informasi yang } \\
\text { memadai untuk mengimplementasikan layanan } \\
\text { kesehatan mental bagi ABK di sekolah }\end{array}$ & 5 & 4 \\
\hline \multirow[t]{3}{*}{ Kesesuaian } & $\begin{array}{l}\text { Buku panduan menuliskan pembagian tugas } \\
\text { secara jelas tentang apa yang harus dilakukan, } \\
\text { oleh siapa dan kapan sehingga tidak } \\
\text { menimbulkan pemaknaan yang beragam dari } \\
\text { pembaca }\end{array}$ & 4 & 5 \\
\hline & $\begin{array}{l}\text { Buku panduan memuat prosedur pelaksanaan } \\
\text { program layanan kesehatan mental berbasis } \\
\text { sekolah bagi ABK dengan jelas yang mampu } \\
\text { mengarahkan pembaca ke arah solusi }\end{array}$ & 5 & 5 \\
\hline & Jumlah Skor & 58 & 56 \\
\hline
\end{tabular}

an khusus. Berdasarkan penilaian ahli psikologi anak berkebutuhan khusus dan ahli pendidikan khusus dapat disimpulkan bahwa rancangan buku panduan yang telah dibuat dinyatakan layak untuk diujicobakan ke lapangan dengan terlebih dahulu dilakukan revisi. Revisi dilakukan sesuai saran dan masukan yang diberikan oleh validator untuk menyempurnakan rancangan buku yang telah disusun. Selanjutnya, rancangan buku panduan ini dapat segera dilakukan uji coba lapangan. 


\section{DAFTAR PUSTAKA}

Balogh, R., et al.(2010). Hospitalisation rates for ambulatory care sensitive conditions for person with and without an intellectual disability-a population perspective. Journal of Intellectual Disability Research, 54 (9), 820-832.

Borg, W. R. \& Gall, M. D. (1983). Educational Research, An Introduction. Fourth Edition. New York: Longman.

Caruana, J. A., et al. (2011). A Special School Community: An Inclusive Setting for Addressing the Mental Health Needs of Students with An Intellectual Disability. Dalam D. Dessetor, D. White, \& L. Whatson, Mental Health of Children and Adoslescents with Intellectual and Development Disabilities. Melbourne: IP Communications.

Chan, J., Hudson, C., \& Vulic, C. (2004). Services for adults with intellectual disability and mental illness: Are we getting it right? Australian e-Journal for the Advancement of Mental Health, 3 (1), 1-6.

Hudson, C., \& Chan, J. (2002). Individuals with intellectual disability and mental illness: A literature review. Australian Journal of Social Issues, 37 (1), 31-50.

Paternite, C. E. (2005). School-Based Mental Health Programs and Services: Overview and Introduction to the Special Issue. Journal of Abnormal Child Psychology, 33 (6), 657-663.

Purwandari, Aini Mahabbati, \& Atien Nur Chamidah. (2013). Pengembangan Model Layanan Kesehatan Mental Berbasis Sekolah bagi Anak Berkebutuhan Khusus di Yogyakarta. Laporan Penelitian Hibah Bersaing 2014. Lembaga Penelitian dan Pengabdian Masyarakat UNY. Tidak diterbitkan. 